\title{
An unusual case of recurrent pneumonia
}

\author{
Robert Corns, Krzysztof R M Rakowski, Giles Critchley, \\ Department of Neurosurgery, Hurstwood Park Neurological Centre, Haywards Heath, UK \\ Correspondence to Robert Corns, cilfodan@hotmail.com
}

\section{Summary}

A gentleman, aged 54, with shunted hydrocephalus presented with recurrent chest infections. He had a ventriculoperitoneal (VP) shunt inserted when he was 38 years old for obstructive hydrocephalus due to a cerebellar tumour, with no subsequent shunt revisions since. Over a 2-year period, he presented with three episodes of pneumonia, which, on each occasion, responded well to antibiotics but then subsequently recurred. A chest x-ray identified the distal end of the VP shunt above the level of the diaphragm. CT scan found the distal end of the shunt tubing to be within a pulmonary bronchus. The VP shunt was revised and the patient had no subsequent recurrences of his chest infections. The authors review the complications of VP shunt placement including the more common sites of shunt tubing migration.

\section{BACKGROUND}

Complications of ventriculoperitoneal (VP) shunts can potentially occur anywhere along their course from the cerebral ventricle to the peritoneal cavity. In our case presented here, the presenting complaint was three episodes of right-sided lobar pneumonia. Recurrent chest infections should be considered suspicious and may indicate lung cancer or immunodeficiency. Recurrent chest infections require further investigation with a chest $\mathrm{x}$-ray in the first instance. This case highlights that there are other rarer causes of recurrent chest infections. Furthermore, it illustrates the unusual way in which VP shunt complications may present. Despite being rare, it is a complication that can be easily rectified.

\section{CASE PRESENTATION}

A right-handed gentleman, aged 54, with shunted hydrocephalus presents with recurrent right-sided

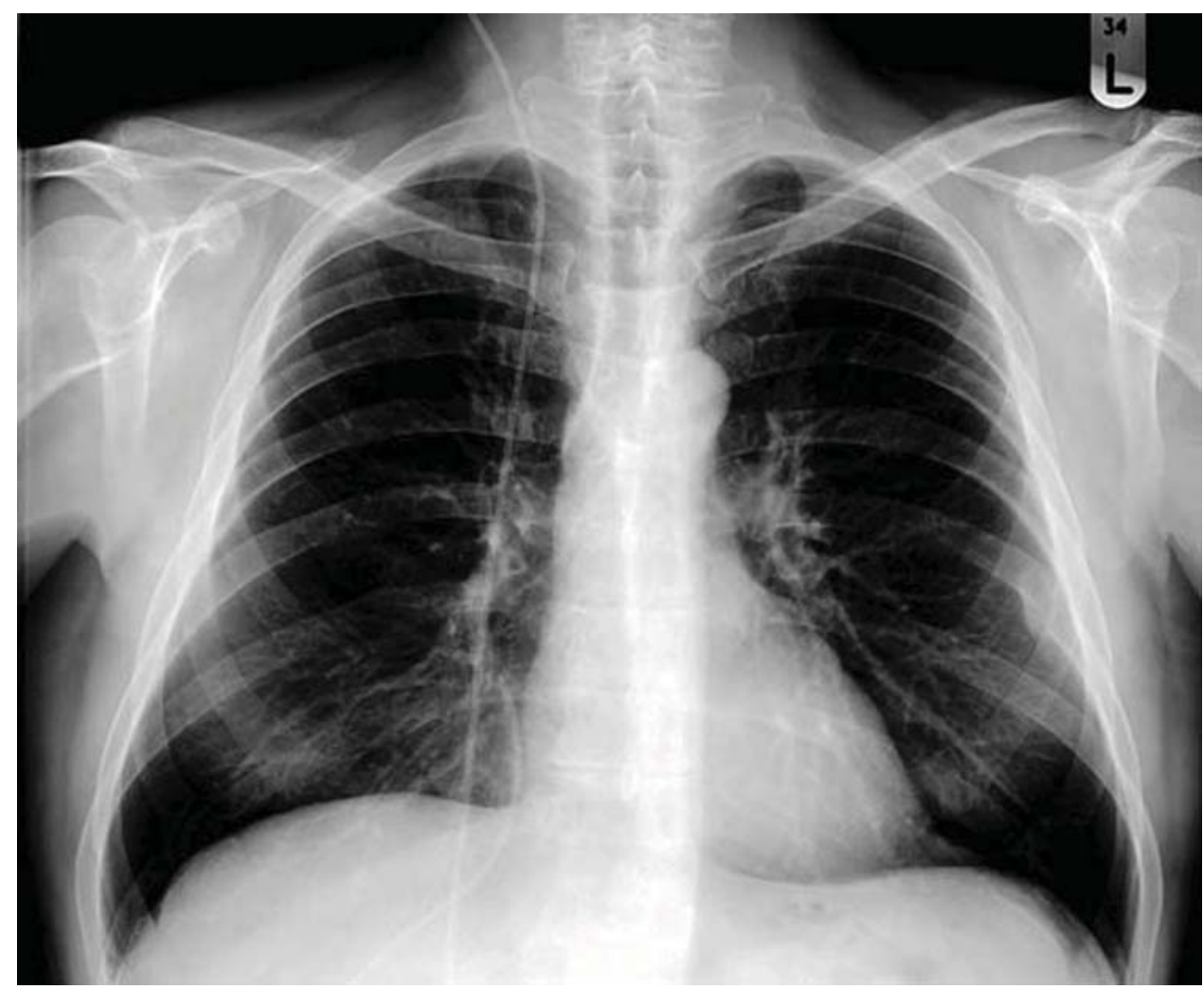

Figure 1 Chest x-ray: distal end of the shunt seen above the level of the diaphragm. 


\section{BMJ Case Reports}

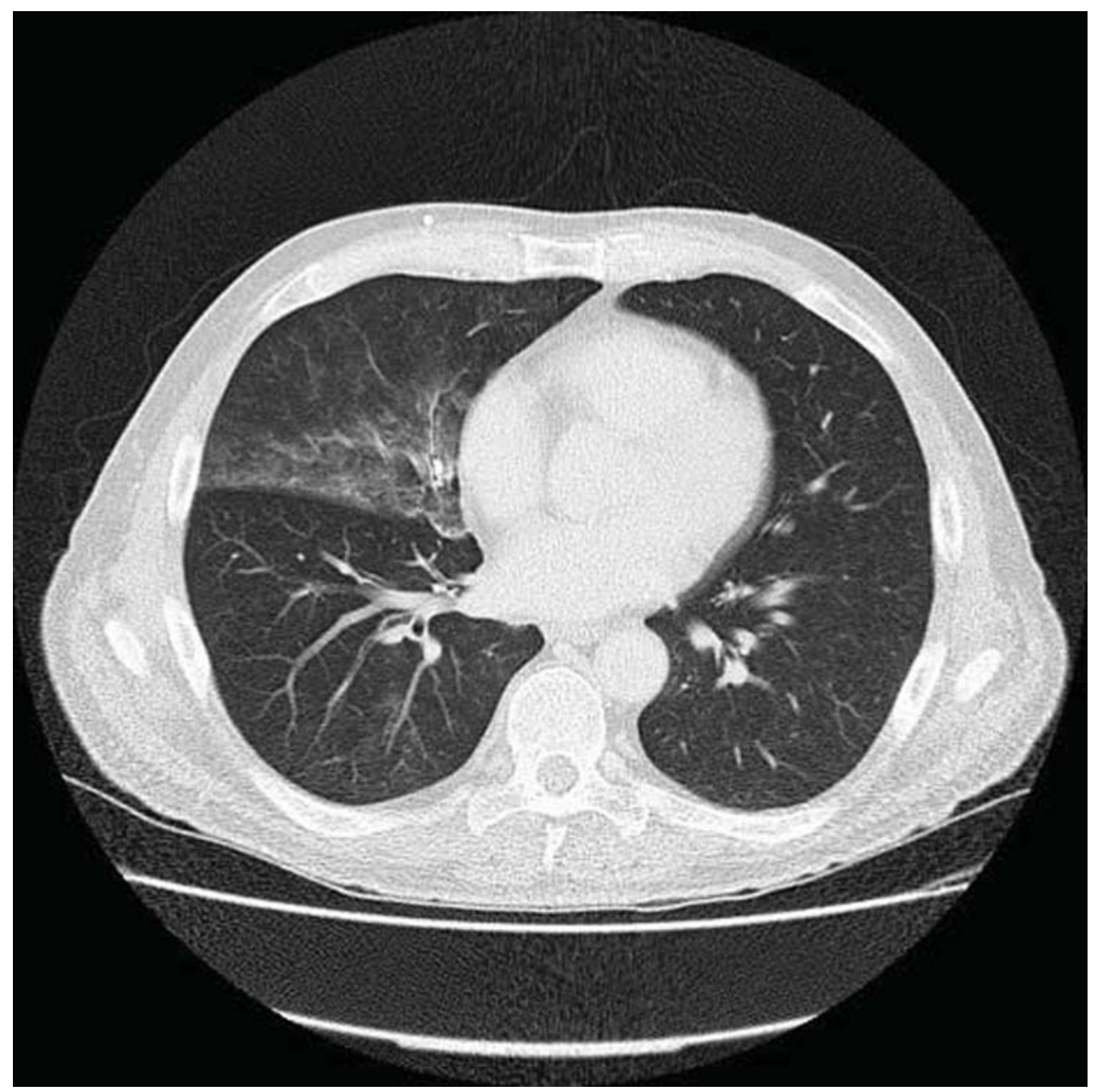

Figure 2 CT scan confirmed the distal end of the shunt tubing to be within a right-sided bronchus.

lobar pneumonia. He initially presented with obstructive hydrocephalus due to a lesion in the cerebellar vermis when he was 38 years old; a biopsy confirmed this to be a haemangioblastoma. Further similar lesions were found in the tectal plate and spleen, leading to a diagnosis of von Hippel Lindau disease. He had a VP shunt inserted in 1994 with no subsequent revisions. He underwent stereotactic radiotherapy for the brain lesions. After a period of remaining clinically and radiologically stable, the cerebellar lesion had recently increased in size and he is awaiting further stereotactic radiosurgery.

Over a 2-year period, he presented with three episodes of right-sided lobar pneumonia, which, on each occasion, responded well to antibiotics but then subsequently recurred. The recurrent infections stopped him being given a general anaesthetic for an operation on haemorrhoids, and he could not undergo a spinal anaesthetic due to his growing posterior fossa tumour.

\section{INVESTIGATIONS}

A chest X-ray identified the distal end of the shunt above the level of the diaphragm (figure 1). CT scan confirmed the distal end of the shunt tubing to be within a right-sided bronchus (figure 2).

\section{OUTCOME AND FOLLOW-UP}

The patient was admitted electively and the distal end of the VP shunt was revised and shortened. The intrathoracic portion was removed and a new peritoneal catheter was connected and re-implanted into the peritoneal cavity. He has had no subsequent recurrence of chest infections.

\section{DISCUSSION}

Complications of VP shunts can potentially occur anywhere along their course from the cerebral ventricle to the peritoneal cavity. ${ }^{1}$ Thoracic complications of VP shunts are rare, as they do not normally enter the thorax. ${ }^{1}$ Migration of VP shunts into the thoracic cavity can be classified as either supradiaphragmatic (where there is no part of the shunt below the diaphragm, as seen on imaging) or transdiaphragmatic (where the shunt passes from below the diaphragm into the thoracic cavity). ${ }^{1}$

It has been speculated that the mechanism for the migration may be the slow drawing back of the catheter into the thorax by negative inspiratory pressures. ${ }^{2}$ Other possible mechanisms have been suggested: migration occurring after an abdominal inflammatory process or via a hiatus or congenital fenestrations in the diaphragm. ${ }^{2}$ 


\section{Learning points}

- Recurrent chest infections are considered especially suspicious as they may indicate underlying lung cancer ${ }^{24}$ or immunodeficiency. ${ }^{25}$

- Recurrent chest infections require further investigation with a chest $x$-ray in the first instance. ${ }^{24}$

- This case highlights a rare complication of VP shunt placement; once the diagnosis has been made, it can be effectively resolved with surgery.

Karapolat et af classify the thoracic complications of VP shunts as follows: intrathoracic trauma during the placement of a shunt, migration of the peritoneal catheter into the chest by either a supradiaphragmatic or transdiaphragmatic route and pleural effusion accompanying cerebrospinal fluid (CSF) ascites. ${ }^{1}$ Of these, the migration of the peritoneal end of the VP shunt into the chest accounts for the majority of thoracic complications. ${ }^{1}$

Transdiaphragmatic migration of a VP shunt followed by the perforation of a bronchus has been previously reported twice. ${ }^{13}$ It has been suggested that in one of these cases peritoneal inflammation or a low-grade infection could have facilitated the erosion of the tip of the shunt through the diaphragm and into the bronchial wall. ${ }^{1}$ The perforation of a bronchus by a shunt has previously been seen with ventriculopleural ${ }^{4}$ and ventriculoatrial ${ }^{56}$ shunts. ${ }^{1}$

The migration of VP shunts has been reported to have occurred in many different anatomical locations, including the scrotum, ${ }^{7}$ (via the inguinal canal), ${ }^{8}$ intracranial dislocations of the catheter, ${ }^{9}$ pulmonary artery, ${ }^{10}$ under silicone breast implants, ${ }_{11}^{11}$ heart, ${ }^{12}{ }^{13}$ bladder, ${ }^{14}$ gallbladder, ${ }^{15}$ vagina, ${ }^{16}{ }^{17}$ gastrointestinal tract, ${ }^{18}$ (including bowel perforations) ${ }^{19}$ and chest ${ }^{20}$ (including into the pleural space). ${ }^{21}$ There have also been reported cases of VP shunt migration to the umbilicus,,$^{22}$ anus $^{17}$ and internal jugular vein. ${ }^{23}$

Ventriculopleural shunts and VP shunts that have migrated into the thoracic cavity can cause a pleural effusion due to the flow of CSF into the chest exceeding the resorptive capacity of the pleura, with respiratory compromise being the usual presenting symptom. ${ }^{1}$ Other respiratory complications also include pneumothorax, bronchial fistula, hydrothorax and empyema. ${ }^{2}$ In one previous case of bronchial perforation, the patient developed a pneumonia. ${ }^{3}$

Competing interests None

Patient consent Obtained.

\section{REFERENCES}

1. Taub $\mathbf{E}$, Lavyne MH. Thoracic complications of ventriculoperitoneal shunts: case report and review of the literature. Neurosurgery 1994;34:181-3; discussion 183-4.

2. Karapolat S, Onen A, Sanli A. Intrathoracic migration of ventriculoperitoneal shunt: a case report. Cases J 2008;1:42

3. Rao CC, Krishna G, Haselby K, et al. Ventriculobronchial fistula complicating ventriculoperitoneal shunt. Anesthesiology 1977;47:388-90.

4. Kessler LA, Stern WZ. The ventriculopleural shunt procedure for hydrocephalus. Case report of an unusual complication. J Pediatr 1962;60:418-20

5. Isamat $\mathbf{F}$. Bronchovenous fistula as a late complication of a ventriculoatriostomy. Case report. J Neurosurg 1969;31:574-5.

6. von Rohden L, Büttner HH, Vinz H. Liquordränage in das bronchialsystem: eine ungewöhnliche Spätkomplikation nach ventrikulo-kardialer shuntoperation. Pädiat Prax 1971;10:585-92.

7. Agarwal T, Pandey S, Niranjan A, et al. Unusual complication of ventriculoperitoneal shunt surgery. J Pediatr Neurosci 2009:4:122-3.

8. Gocer Al, Bagdatoglu H, Cetinalp E, et al. An unusual complication of the ventriculo-peritoneal shunt: migration of the distal end into the scrotum through the inguinal canal. Turk Neurosurg 1990;1:176-7.

9. Pereira CU, Santos EAS. Intracranial migration of a ventriculo-peritoneal shunt catheter. Intern J Pediatr Neonatol 2005:4:30-2.

10. Hermann EJ, Zimmermann M, Marquardt G. Ventriculoperitoneal shunt migration into the pulmonary artery. Acta Neurochir (Wien) 2009;151:647-52.

11. Mudo ML, Amantéa AV, Joaquim AF, et al. Distal migration of ventriculoperitoneal shunting catheter under silicon breast implant. Arq Neuropsiquiatr 2009;67(3A):697-8.

12. Ruggiero C, Spennato P, De Paulis D, et al. Intracardiac migration of the distal catheter of ventriculoperitoneal shunt: a case report. Childs Nerv Syst 2010;26:957-62.

13. Ramani PS. Extrusion of abdominal catheter of ventriculoperitoneal shunt into the scrotum. Case report. J Neurosurg 1974;40:772-3.

14. Surchev J, Georgiev K, Enchev Y, et al. Extremely rare complications in cerebrospinal fluid shunt operations. J Neurosurg Sci 2002;46:100-2; discussion 103

15. Portnoy HD, Croissant PD. Two unusual complications of a ventriculoperitoneal shunt. Case report. J Neurosurg 1973;39:775-6.

16. Farrokhi MR, Tavallaee GH. Unusual migration of the distal catheter of a ventriculoperitoneal shunt into the vagina. Iran J Med Sci 2007;32:182-4.

17. Patel CD, Matloub H. Vaginal perforation as a complication of ventriculoperitoneal shunt. Case report. J Neurosurg 1973:38:761-2.

18. Cheng JY, Lo WC, Liang HH, et al. Migration of ventriculoperitoneal shunt into the stomach, presenting with gastric bleeding. Acta Neurochir (Wien) 2007:149:1269-70.

19. Birbilis T, Zezos P, Liratzopoulos N, et al. Spontaneous bowel perforation complicating ventriculoperitoneal shunt: a case report. Cases J 2009;2:8251.

20. Sahin S, Shaaban AF, Iskandar BJ. Recurrent pneumonia caused by transdiaphragmatic erosion of a ventriculoperitoneal shunt into the lung. Case report. J Neurosurg 2007:107(2 Suppl):156-8.

21. Rahimi Rad MH, Mirzaagazadeh J, Ansarin K. Supradiaphragmatic and transdiaphragmatic intrathoracic migration of a ventriculoperitoneal shunt catheter. Hong Kong Med J 2007:13:147-9.

22. Wani AA, Ramzan A, Wani MA. Protrusion of a peritoneal catheter through the umblicus: an unusual complication of a ventriculoperitoneal shunt. Pediatr Surg Int 2002;18:171-2.

23. Imamura $\mathbf{H}$, Nomura M. Migration of ventriculoperitoneal shunt into the heart-case report. Neurol Med Chir (Tokyo) 2002;42:181-3.

24. South West London Cancer Network. Referral for suspected cancer: GP advice pack. (Updated for NICE Clinical Guideline CG29 June 2005), 2006.

25. Nandakumar K, Ahmed I, Bhutt R. What is the rare but well-documented cause of this recurrent chest infection? Breathe 2007;3:383-5. 


\section{BMJ Case Reports}

This pdf has been created automatically from the final edited text and images.

Copyright 2011 BMJ Publishing Group. All rights reserved. For permission to reuse any of this content visit http://group.bmj.com/group/rights-licensing/permissions.

BMJ Case Report Fellows may re-use this article for personal use and teaching without any further permission.

Please cite this article as follows (you will need to access the article online to obtain the date of publication).

Corns R, Rakowski KRM, Critchley G. An unusual case of recurrent pneumonia. BMJ Case Reports 2011;10.1136/bcr.10.2010.3380, date of publication

Become a Fellow of BMJ Case Reports today and you can:

- Submit as many cases as you like

- Enjoy fast sympathetic peer review and rapid publication of accepted articles

- Access all the published articles

- Re-use any of the published material for personal use and teaching without further permission

For information on Institutional Fellowships contact consortiasales@bmjgroup.com

Visit casereports.bmj.com for more articles like this and to become a Fellow 